\title{
STRATEGI BRANDING MELALUI INOVASI DESAIN KEMASAN BAGI HOME INDUSTRY SABUN CAIR
}

\author{
Nadia Sigi Prameswari ${ }^{1}$, Mohamad Suharto ${ }^{2}$, Esty Wulandari ${ }^{3}$ \\ ${ }^{1}$ Fakultas Bahasa dan Seni, Universitas Negeri Semarang \\ ${ }^{23}$ Fakultas Seni Rupa dan Desain, Universitas Sebelas Maret Surakarta \\ Jl. Sekaran, Gunung Pati, Kota Semarang, Jawa Tengah 50229 \\ nadiasigi87@gmail.com ${ }^{1}$
}

\begin{abstract}
Abstrak: Industri Rumah Tangga merupakan salah satu wujud dari Usaha Mikro Kecil Menengah (UMKM) yang memproduksi barang-barang dan dilakukan di dalam rumah serta berskala kecil. King Queenclong dan Star Sabun Herbal merupakan produk home industry sabun cair di kota Surakarta. Saat ini produk sabun cair tersebut telah dikemas dalam botol ukuran $300 \mathrm{ml}$ dan terdapat label yang menunjukkan identitas produk, namun saat ini penjualan kian menurun lantaran banyaknya kompetitor produk sejenis dengan desain kemasan yang lebih memukau sehingga menarik minat beli masyarakat. Oleh karena itu, diperlukan suatu upaya inovasi branding melalui packaging dan labelling. Hasil penelitian terhadap responden menunjukkan faktor utama dalam memilih produk sabun adalah desain kemasan, faktor selanjutnya adalah harga dan isi. Berdasarkan observasi yang dilakukan, telah diujicobakan desain kemasan sabun cuci piring pada responden diantaranya adalah bentuk botol pump volume $300 \mathrm{ml}$, warna botol bening dengan label warna hijau dan putih. Sedangkan bentuk botol untuk sabun cuci tangan adalah botol flip top volume $300 \mathrm{ml}$, warna botol bening dengan label warna ungu-putih (Sabun King Queenclong) dan label warna hijau-putih (Star Sabun Herbal). Inovasi branding ini diharapkan dapat memberi dorongan kepada konsumen untuk membeli produk sabun cair King Queenclong dan Star Sabun Herbal.
\end{abstract}

Kata kunci: branding, desain kemasan, label, industri rumah tanga.

Abstract: Home Industry is one form of Micro Small Medium Enterprises (SMES) that produces goods made in houses and small scale. King Queenclong and Star Sabun Herbal is a home product of liquid soap industry in Surakarta city. Currently the liquid soap product has been packaged in $300 \mathrm{ml}$ bottle and there is a label that shows the identity of the product, but the current sales declines due to many competitors' similar products with more fascinating packaging design to attract public interest. Therefore, it needs an innovation branding effort through packaging and labelling. The result of the research on the respondents shows the main factor in choosing the soap product is the packaging design, the next factor is the price and the contents. Based on observations made, it has been tested the design of dish soap packaging on respondents such as the form of $300 \mathrm{ml}$ bottle pump bottle, clear color bottle with green and white label. While the form of a bottle for hand washing soap is a $300 \mathrm{ml}$ flip top volume bottle, a clear bottle color with a purple-

Penulis adalah staf pengajar di Universitas Negeri Semarang dan beberapa staf pengajar di Universitas Sebelas Maret Surakarta. 
white label (King Queenclong Soap) and a green-and-white label (Star Herbal Soap). This branding innovation is expected to encourage consumers to buy King Queenclong liquid soap and Star Soap Herbal products.

Keywords: branding, packaging design, label, home industry.

\section{PENDAHULUAN}

Home industry atau industri rumah tangga merupakan suatu industri atau kegiatan memproduksi barang-barang yang dilakukan di rumah dan berkala kecil. Usaha kecil mempunyai peran penting dalam pertumbuhan ekonomi suatu Negara (Zuhri, 2013; Sasono \& Yuliana, 2014). Home industry atau Industri rumah tangga adalah salah satu wujud dari Usaha Mikro Kecil Menengah (UMKM). Perkembangan jumlah industri rumah tangga dari tahun ke tahun semakin bertambah. Dalam suatu industri kecil terdapat beberapa aspek yang dibutuhkan untuk bisa mendukung berjalannya suatu industri tersebut, diantaranya adalah modal, bahan baku, tenaga kerja, pemasaran, serta konsumen (Irrubai, 2016).

Saat ini telah banyak home industry yang berkembang di masyarakat. Salah satu produk home industry ini adalah sabun cair yang memiliki banyak fungsi. Sabun merupakan suatu macam surfaktan (bahan surface active), merupakan senyawa yang menurunkan tegangan permukaan air. Sifat inilah yang menyebabkan larutan sabun dapat memasuki berbagai serat sehingga dapat mengurangi serta menghilangkan berbagai kotoran dan minyak (Sari et al., 2010). Sabun merupakan pencuci pakaian dan pembersih kulit yang digunakan oleh masyarakat (Anggraini, et al., 2012).

Kehadiran sabun cuci cair memberikan nilai praktis bagi penggunanya dalam pemanfaatannya untuk membersihkan peralatan-peralatan rumah tangga. Selain itu, sifat sabun cair yang mudah larut didalam air dan aroma produk yang khas menjadikan cairan pencuci piring memiliki nilai lebih dibanding produk 
pencuci piring lainnya (Widyasanti, et. al., 2017). Keuntungan lain yang didapatkan ketika menggunakan sabun cuci cair yaitu lebih higienis (Haro et al., 2017).

Kebutuhan akan produk sabun cair semakin lama semakin meningkat sehingga banyak berbagai produk sabun cair yang bisa ditemukan di pasaran. Pada prinsipnya dalam pembuatan dan proses produksi sabun cair dalam skala home industry tidak serumit bila dibandingkan dengan pembuatan sabun pembersih lainnya (pasta atau powder). Proses produksi pembuatan sabun cair ini harus diimbangi pula dengan strategi branding (labelling dan packaging) untuk memaksimalkan penjualan. Salah satu produk home industry sabun cair di kota Surakarta adalah sabun cair King Queenclong milik Bapak Widodo dan Star Sabun Herbal milik Pak Ruswinarto. Saat ini produk sabun cair tersebut telah dikemas dalam botol ukuran $300 \mathrm{ml}$ dan sudah diberi label.

Perkembangan industri rumah tangga saat ini, dalam aspek mutu atau kualitas terutama dalam hal strategi branding (labelling dan packaging) secara umum hanya sedikit yang mengalami peningkatan (Irrubai, 2016). Kemasan atau packaging adalah suatu wadah yang menempati suatu barang agar aman, menarik, mempunyai daya pikat bagi seseorang yang ingin membeli suatu produk (Mukhtar dan Nurif, 2015). Kemasan suatu produk dapat memberikan pengaruh yang penting dalam mempertahankan atau meningkatkan penjualan (Syamsudin dan Wadji, 2015). Berdasarkan penelitian yang dilakukan oleh Pesoth (2015) Packaging dan Brand Image secara simultan berpengaruh positif terhadap kepuasan pelanggan.

Solusi dari permasalahan ini diantaranya perlu diadakannya sebuah upaya yang dapat mengurangi permasalahan tersebut yang bertujuan untuk mendapatkan kepercayaan dari masyarakat dan memiliki target pasar sehingga dapat meningkatkan penjualan produk home industry (Hidayat et al., 2016). Salah satu upaya yang dapat dilakukan antara lain adalah perancangan branding, yang dalam hal ini perancangan packaging dan labelling sabun cuci cair sebagai upaya 
peningkatan brand awareness. Labelling dan packaging merupakan indentitas produk sehingga menjadi salah satu aspek penting yang harus diperhatikan oleh pelaku industri rumah tangga.

Seiring perkembangan jaman, saat ini perusahaan dituntut untuk selalu berkembang dan berinovasi dengan produknya. Persaingan yang kompetitif yang ada saat ini menuntut suatu perusahaan untuk lebih kreatif dalam membuat desain produknya agar lebih menarik dari para pesaing. Salah satu daya tarik yang dapat ditonjolkan dari sebuah produk adalah desain kemasannya. Kekuatan desain kemasan mempunyai pengaruh yang tinggi terhadap keputusan pembelian karena desain kemasan yang unik akan memiliki daya tarik tersendiri bagi para konsumen. Maflahah (2012) menyatakan bahwa sebagian besar kemasan produk UMKM tidak memiliki desain yang menarik, inovatif dan kreatif.

Kemasan merupakan salah satu alat pemasaran yang penting, tidak sekedar sebagai pembungkus. Kemasan (packaging) merupakan proses perancangan dan pembuatan wadah (container) atau pembungkus (wrapper) terhadap sebuah produk (Tjiptono, 2007). Jika pelaku usaha memperhatikan fungsi-fungsi tersebut maka kelancaran penjualan produk dapat meningkat. Charles A. Beresrin petugas Modern Packaging Magazine Amerika dalam Alma (2002) mengatakan bahwa "Pembungkus tidak hanya merupakan pelayanan tetapi juga salesman dan pembawa kepercayaan, dimana suatu pembungkus merupakan penglihatan terakhir dari konsumen yang dapat dipercaya".

\section{Sabun King Queenclong}

Pak Widodo adalah salah satu warga dari Desa Pucang Sawit, Jebres, Surakarta yang mempunyai usaha produksi sabun. Pak Widodo merupakan penyandang difabel tetapi memiliki pemikiran untuk dapat hidup mandiri dengan cara mendirikan usaha pembuatan sabun. Proses produksi dilakukan sendiri di rumah Pak Widodo yang dibantu satu orang pegawai. Usaha produksi sabun ini 
telah ditekuni oleh Pak Widodo selama kurang lebih 3 tahun. Produk Sabun yang dihasilkan yaitu sabun herbal yang mempunyai beberapa variasi seperti sabun mandi, sabun cuci, dan sabun detergen yang semuanya berbentuk liquid (cair) dengan nama Sabun King Queenclong.

Usaha produksi sabun herbal yang ditekuni oleh Pak Widodo ini mempunyai kelebihan yaitu diproduksi tanpa soda api, menggunakan pewarna makanan dan minyak nabati. Selain memproduksi sendiri, Pak Widodo juga menjual sendiri produk sabun tersebut. Omzet yang dihasilkan setiap harinya yaitu sekitar Rp. 400.000,00 dengan keuntungan kurang lebih Rp.50.000 sampai Rp. 100.000,00 setiap harinya.
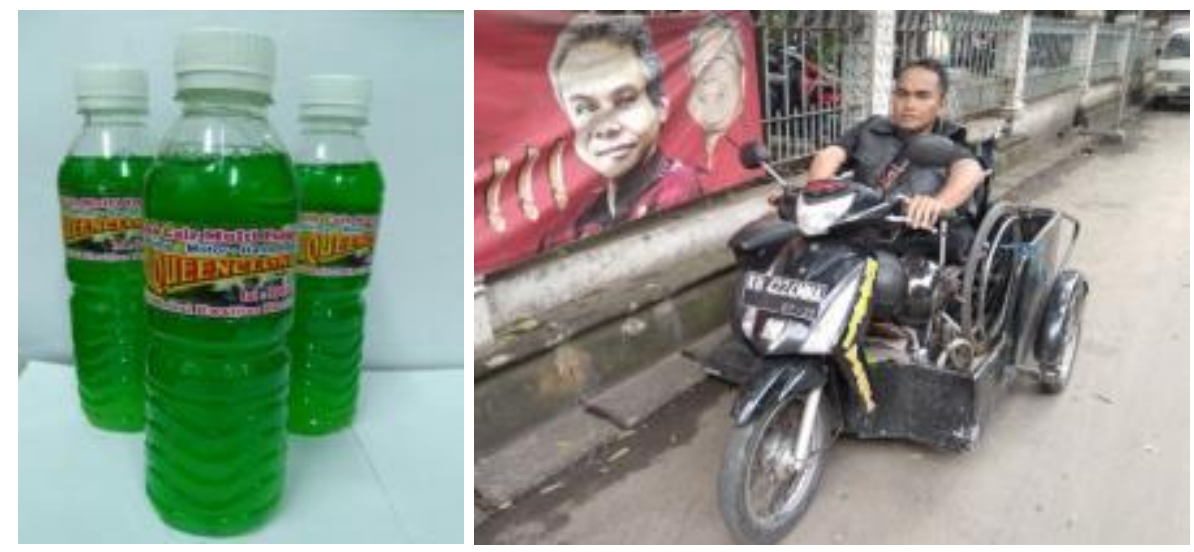

Gambar 1 Pemilik Usaha King Queenclong dan Produk Sabun King Queenclong Sumber: Prameswari dkk, 2018

Setiap harinya Pak Widodo menggunakan sepeda motor roda tiga yang dimodifikasi khusus bagi penyandang difabel dan sekaligus menjadi stand tempat memamerkan produk untuk berjualan. Pemasaran produk sabun dilakukan dengan cara door to door dari daerah Gawok, Sukoharjo hingga Pasar Kliwon, akan tetapi booth atau stand yang digunakan kurang layak dikarenakan kurangnya fasilitas yang memadai sehingga membuat pelanggan menjadi kurang nyaman. Hal 
ini diperparah jika kondisi cuaca buruk atau hujan. Booth tersebut tidak dapat memuat pelanggan, sehingga mengakibatkan pendapatan akan turun hingga $70 \%$.

\section{Star Sabun Herbal}

Pak Ruswinarto sudah menjalani usaha produksi sabun selama kurang lebih 2 tahun. Produksi dilakukan di rumah Pak Ruswinarto di daerah Luwang, Gatak, Sukoharjo. Setiap harinya Pak Ruswinarto memproduksi sabun herbal dengan naman Star Sabun Herbal. Produk sabun herbal tersebut seperti sabun mandi, sabun mencuci piring dan sabun mencuci baju. Pak Ruswinarto memasarkan produk sabun herbal hasil produksinya dengan menggunakan sepeda motor yang sekaligus difungsikan sebagai stand tempat memamerkan produknya. Omzet yang didapat setiap harinya kurang lebih Rp.300.000,00 dengan keuntungan Rp.80.000,00.

Pemasaran yang dilakukan oleh Pak Ruswinarto di daerah Gawok, Sukoharjo dan belum dapat meluas karena stand yang disediakan kurang memadai. Stand tersebut hanya hasil modifikasi sendiri tapi belum layak karena kurangnya sarana untuk membuat stand agar terlihat lebih layak. Hal ini membuat pembeli menjadi kurang nyaman untuk membeli produk sabun herbal tersebut. Pemasaran saat ini dilakukan sendiri oleh Pak Ruswinarto dengan berkeliling dan belum di dukung menggunakan media promosi lain.
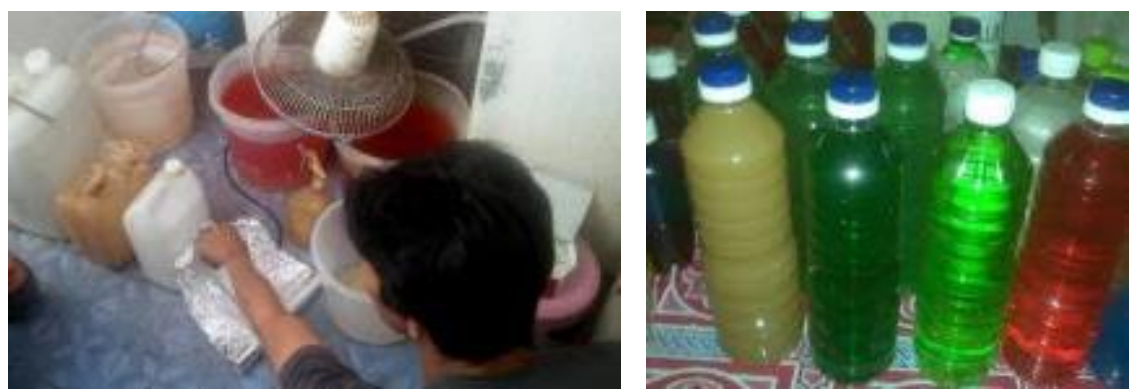

Gambar 2 Proses Pengolahan Sabun dan Produk Star Sabun Herbal Sumber: Prameswari dkk, 2018 
Berdasarkan pada kondisi tersebut, maka dapat ditarik rumusan masalah yaitu bagaimana inovasi tampilan produk dan desain label sabun cuci cair yang menarik. Untuk itu perlu adanya pengembangan branding (packaging dan labelling) home industry sabun cair King Queenclong dan Star Sabun Herbal. Salah satu caranya adalah dengan membuat inovasi branding yaitu tampilan kemasan (botol) dan desain label baru. Adanya inovasi branding ini dimaksudkan agar produk dapat dengan mudah dipromosikan dan menjadi daya tarik bagi para calon konsumen. Dengan inovasi branding ini, produk akan memiliki perbedaan dengan pesaingnya bila memiliki brand yang kuat. Selain itu branding juga berfungsi sebagai pembangun citra produk, pemberi keyakinan kepada konsumen, dan jaminan kualitas produk.

\section{KAJIAN TEORI}

\section{Branding Home industry}

Merek (Brand) adalah identitas tambahan suatu produk yang bukan hanya membedakan dari produk pesaing, tetapi juga janji dari produsen kepada konsumen bahwa produk tersebut akan selalu dapat menyampaikan nilai yang diharapkan konsumen dari sebuah produk. Tjiptono (2007) menyatakan bahwa merek merupakan aset strategik terpenting seperti perusahaan yang mampu menciptakan nilai atau manfaat bagi pelanggan dan perusahaan.

Brand tidak hanya sekedar nama dan logo, tetapi janji suatu organisasi kepada konsumen untuk memberikan apa yang menjadi prinsip Brand tersebut serta bermanfaat dalam hal fungsional, emosional, ekspresi diri dan sosial. Merek mulai mendapatkan perhatian khusus setelah para pelaku usaha menilai bahwa brand memiliki peran penting dalam penjualan produk mereka. Brand merupakan asset, memiliki ekuitas dan menggerakkan strategi serta performa bisnis. Pengelolaan dan manajemen Brand kini menjadi isu penting 
untuk dibahas terkait strategi perusahaan dalam menjaga kesetiaan konsumennya (Aaker, 2014). Gelder dalam Kusno dkk (2007) mendefinisikan strategi branding sebagai apa yang seharusnya dicapai suatu brand dalam kaitannya dengan sikap dan perilaku konsumen. Strategi merek adalah suatu manajemen brand yang bertujuan untuk mengatur semua elemen brand dalam kaitannya dengan sikap dan perilaku konsumen, atau dapat diartikan sebagai suatu sistem komunikasi yang mengatur semua kontak poin dengan suatu produk atau jasa atau organisasi itu sendiri dengan stakeholder dan secara langsung mendukung bisnis strategi secara keseluruhan.

Pada sebuah konsep branding, yang perlu diperhatikan bukan hanya membuat target pemasaran 'kita' memilih 'kita' di dalam pasar yang penuh kompetisi namun juga membuat prospek-prospek pemasaran melihat merek (brand) kita sebagai satu-satunya yang dapat mengatasi atau memberikan solusi bagi mereka. Berdasarkan hal tersebut maka dalam membangun sebuah brand diperlukan teknik branding yang tepat (Knapp, 2001:15), diantaranya: differentiation, relevance, esteem, awareness, mind. Branding pada produk home industry sangat diperlukan sebagai salah satu upaya untuk meningkatkan kualitas produk sehingga dapat menarik para calon konsumen untuk membeli produk home industry.

\section{Packaging dan Labelling}

Kotler dan Amstrong (2012) mendefinisikan "packaging involves designing and producing the container or wrapper for a product" yang artinya adalah proses kemasan melibatkan kegiatan mendesain dan memproduksi wadah dari sebuah produk.

Kemasan merupakan hal yang penting karena dapat juga digunakan sebagai media promosi untuk memikat konsumen sehingga konsumen berkeputusan untuk melakukan pembelian produk yang bersangkutan (Susetyarsi, 2012). Kemasan yang menarik dapat mempengaruhi pola beli 
konsumer bagaimana desain kemasan memiliki latar gambar kemasan yang menarik, begitu juga dengan warna kemasan dan font yang digunakan yang berguna untuk mendorong minat belanja konsumen (Karedza \& Sikwila, 2017). Dengan data tersebut, dapat dikatakan bahwa packaging atau kemasan merupakan salah satu hal yang berpengaruh terhadap keputusan konsumen untuk membeli suatu produk dari pelaku usaha (Wildyana dan Suyasa, 2006). Kegiatan promosi dengan desain kemasan memberikan dampak yang signifikan dimana pemasaran mengalami peningkatan (Septiningtyas \& Soewardikoen, 2018).

Tjiptono (2007:106) menyatakan bahwa pemberian kemasan pada produk memiliki beberapa tujuan, yaitu (a) pelindung isi (protection); (b) memberikan kemudahan dalam penggunaan (operation); (c) bermanfaat dalam pemakaian ulang (reusable); (d) memberi daya tarik (promotion) berupa aspek artistik, warna, bentuk, dan desain; (e) sebagai salah satu identitas produk (image); (f) memudahkan proses distribusi (shipping); dan (g) dapat memberikan informasi (labelling) yang menyangkut isi, pemakaian, kualitas, dan sebagai cermin dalam inovasi produk.

Pemanfaatan teknologi dapat mempengaruhi perkembangan suatu usaha (Suharto, et.al, 2017). Tampilan kemasan perlu diperhatikan dalam memberikan daya tarik terhadap produk (Sutawikara, 2017). Konsumen membuat pilihan pembelian berdasarkan persepsi mereka dimulai dari daya tarik tampilan visual dan nilai yang melekat pada suatu produk yang ditawarkan (Sutojo dan Kleinsteuber, 2002). Desain kemasan memiliki variabel yang terdiri dari 3 dimensi, yaitu desain grafis, struktur desain, dan informasi produk.

Menurut Klimchuk \& Krasovec (2007), pemasar harus sekreatif mungkin dalam penciptaan desain kemasan, karena desain kemasan yang menarik dan unik dapat meningkatkan minat beli konsumen. Kotler dan 
Amstrong (2012) menjelaskan bahwa dalam proses kemasan melibatkan kegiatan mendesain dan memproduksi wadah dari sebuah produk.

Desain grafis merupakan dekorasi visual pada permukaan kemasan (Nilsson \& Ostrom dalam Cahyorini \& Rusfian, 2011) yang terdiri dari empat sub dimensi, yaitu: nama merek, warna, tipografi, dan gambar. Struktur desain terkait dengan fisik kemasan terdiri dari 3 subdimensi, yaitu: bentuk (shape), ukuran (size), dan material.

Salah satu fungsi kemasan merupakan media penyampaian pesan terhadap produk melalui informasi yang tertera dalam desain kemasan. Informasi produk dapat membantu konsumen dalam membuat keputusan pembelian dengan lebih selektif (Silayoi \& Speece, 2004). Dimensi-dimensi kemasan berperan dalam menghasilkan kemasan yang menarik dan estetis. Semakin tinggi daya tarik kemasan akan semakin menarik perhatian konsumen. Fungsi kemasan secara umum adalah protection yaitu melindungi produk dari faktor eksternal (contoh: cuaca, benturan dan sebagainya), mempertahankan produk yang dikemas dalam keadaan bersih dan higienis, utility, mempertahankan gizi atau fungsi produk yang dikemas, mempermudah distribusi, membuat lebih praktis untuk dibawa, media komunikasi, media informasi, dan sebagai sarana promosi atau marketing untuk menarik konsumen mulai dari variasi bentuk, grafis, material dan sebagainya (Grundey, 2010).

Lieven, et al (2014) menjelaskan bahwa elemen desain pada sebuah brand dapat memberikan citra, gambaran brand, keunikan sekaligus identitas bagi brand kemasan tersebut. Citra positif yang dihasilkan dari suatu kemasan memungkinkan kemasan tersebut dapat meningkatkan citra baik bagi suatu brand atau merek (Sohier, 2009; Anandia, 2015). 


\section{METODE PENELITIAN}

\section{Jenis dan Pendekatan Penelitian}

Objek telaah dalam penelitian ini adalah strategi branding produk hasil industri rumah tangga sebagaimana yang akan didapatkan dari sumber informasi yaitu pelaku usaha indutri rumah tangga sabun cuci cair. Sumber informan yang lain yaitu konsumen dari Star Sabun Herbal dan Sabun King Queenclong. Jenis penelitian ini adalah kualitatif dengan menggunakan metode deskriptif. Dengan demikian penelitian yang dilakukan ini berusaha mendeskripsikan kegiatan para pelaku usaha industri rumah tangga sabun cuci cair dalam hal strategi branding.

\section{Teknik Pengumpulan Data}

Observasi dilakukan untuk memperoleh data tentang upaya yang dilakukan masyarakat untuk reaktulisasi kembali yang nantinya akan dapat ditemukan esensi permasalahan yang menjadi fokus penelitian. Teknik observasai memiliki perbedan yang signifikan antara observasi kualitatif dengan observasi pada paradigma kuantitatif. Observasi kualitatif tidak dibatasi kategorisasikategorisasi pengukuran (kuantitatif) dan tanggapan yang telah diperkirakan terlebih dahulu (Hasanah, 2016: 23). Denzin \& Lincoln (2009: 524), menyebutkan bahwa observasi kualitatif digunakan untuk memahami latar belakang dengan fungsi yang berbeda antara yang obyektif, interpretatif interaktif, dan interpretatif grounded. Observasi dilakukan pada proses jual beli antara pemilik usaha dengan calon pembeli sehingga dapat diketahui sejauh mana kekurangan dan kelebihan pemilik usaha dalam melayani calon pembeli.

Wawancara adalah percakapan yang dilakukan oleh dua pihak, yaitu pewawancara (interviewer) yang mengajukan pertanyaan dan yang diwawancarai (interviewer) yang memberikan jawaban atas pertanyaan. Wawancara digunakan sebagai teknik pengumpulan data apabila peneliti 
akan melaksanakan studi pendahuluan maupun menelusuri inti dari penelitian yang berguna menemukan permasalahan yang harus diteliti, dan juga peneliti ingin mengetahui hal-hal dari responden yang lebih mendalam dan jumlah respondennya sedikit atau kecil (Sugiyono, 2010: 194).

\section{Teknik Analisis Data}

Data mentah (soft data) merupakan data yang telah terkumpul dari lapangan, berupa uraian-uraian yang penuh deskripsi mengenai kegiatan subyek yang diteliti yang diperoleh melalui observasi dan wawancara. Menurut S. Nasution (dalam Sugiyono, 2008) menjelaskan bahwa "Analisis data kualitatif adalah proses menyusun data yang berarti menggolongkannya dalam pola, tema atau kategorisasi agar dapat ditafsirkan". Berangkat dari pengertian ini maka teknik analisis data yang lakukan dalam penelitian ini meliputi, pertama, mengolah data. Kedua, memilah-milah data primer, skunder dan lainnya. Ketiga, memilih data yang tingkat kehandalannya tinggi dan keterhandalannya rendah. Keempat, mencari data pendukung bagi data yang tingkat keterhandalannya rendah. Kelima, kegiatan terakhir adalah menginterpretasikan data yang sudah dikhususkan untuk selanjutnya dimaknakan dengan bahasa yang baik dan benar, kemudian disimpulkan. Seluruh data yang sudah diperoleh akan dianalisis menggunakan teknik analisis domain (domain analysis) yaitu memperoleh gambaran yang umum dan menyeluruh dari obyek penelitian.

\section{HASIL DAN DISKUSI}

Packaging dan labelling menjadi dua hal yang sangat penting dalam suatu produk untuk menarik para konsumen. Belum adanya pengemasan (packaging) dan labelling pada industri menyebabkan jumlah produksi tidak dapat dimaksimalkan. Berdasarkan observasi yang dilakukan terhadap 20 responden 
pembeli, responden akan lebih mempertimbangkan isi (volume sabun) dan harga sabun dalam memilih produk sabun cair yang akan mereka beli daripada mempertimbangkan bentuk kemasan (warna, gambar, dan konten pada kemasan). Namun tidak dapat disangkal pula bahwa branding (packaging dan labelling) merupakan hal yang sangat penting untuk para pelaku usaha untuk mengoptimalkan usahanya. Hasil penelitian menunjukkan bahwa sebagian responden memiliki kriteria terhadap inovasi kemasan sabun sesuai dengan pilihan yang telah diberikan.

Strategi desain kemasan bertujuan untuk merebut pasar dan memberikan rangsangan kepada konsumen agar membeli produknya. Selain bertujuan untuk merebut pangsa pasar, strategi desain kemasan yang tepat merupakan suatu alat pemasaran yang dapat memberikan self service yaitu merepresentasikan karakteristik dari suatu produk untuk meyakinkan konsumen guna memempengaruhi keputusan pembelian (Tafiprios \& Arbi, 2015: 3). Dengan demikian, timbul dugaan bahwa desain kemasan (packaging) dapat menimbulkan impulsive buying. Impulsive buying didefinisikan sebagai pembelian yang tidak terencana. Berikut ini merupakan permintaan secara umum dari konsumen terhadap produk sabun King Queenclong dan Star Sabun Herbal.

Pertama, mengenai bentuk kemasan dari produk sabun. Berdasarkan hasil observasi terhadap inovasi branding yang akan dilakukan, responden lebih memilih bentuk kemasan botol dengan tutup flip top dan kemasan botol pump dengan volume $300 \mathrm{ml}$. Penggunaan botol flip top dinilai lebih praktis dalam penggunaanya dibandingkan dengan botol lain. Selain itu, botol flip top lebih higienis jika digunakan, dan meminimalisir tumpahnya cairan. Sedangkan untuk pemilihan botol pump dinilai lebih efektif karena penggunaanya sekali tekan sehingga penggunaan lebih hemat dan menghindari tumpahnya cairan. 
Kedua, hal yang menjadi komponen dari branding suatu produk adalah warna. Warna utama yang diinginkan oleh responden adalah bening atau transparan dan putih. Sedangkan warna pendukungnya adalah warna hijau. Ketiga, Konten atau isi dalam label kemasan. Responden menginginkan adanya informasi konten yang perlu ditampilkan pada label kemasan, diantaranya adalah merk, komposisi dan fungsi atau kegunaan. Bagian-bagian konten tersebut diperlukan sebagai informasi terhadap produk dari pelaku usaha. Keempat, label bagi produk sabun. Responden menilai perlunya pemberian gambar pada label kemasan produk yang disesuaikan dengan fungsi dari produk tersebut. Misal adalah gambar piring dan gelas, bila produk tersebut memang digunakan untuk mecuci alat-alat dapur.

Responden merupakan pelanggan dari produk sabun cair King Queenclong dan Star Sabun Herbal saat ini. Responden juga menyatakan bahwa tetap berkenan untuk membeli produk sabun cuci cair King Queenclong dan Star Sabun Herbal ketika kemasan dibuat lebih baik dengan inovasi masa kini meskipun harganya meningkat. Hal ini menunjukkan bahwa responden sangat memperhatikan hal-hal yang berhubungan dengan tampilan kemasan sabun.

Berdasarkan observasi yang telah dilakukan, telah dibuat desain kemasan sabun seperti yang diinginkan oleh para responden. 
1. Desain 1 (Sabun Cuci Piring)

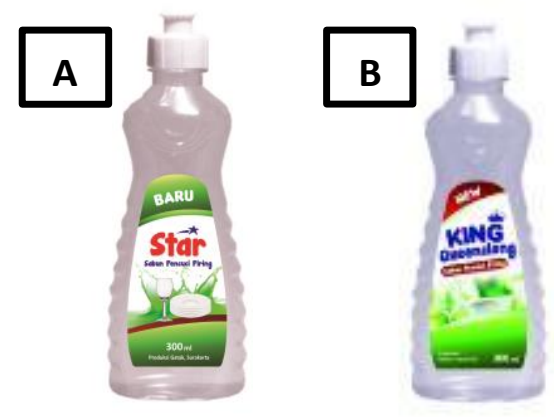

Gambar 3 (A) Desain sabun cuci piring Star Sabun, (B) Desain sabun cuci piring King Queenclong Sumber: Prameswari dkk, 2018

Desain ini dibuat berdasarkan permintaan rata-rata para responden yang menginginkan inovasi kemasan botol pada produk sabun cair. Penggunaan botol flip top ini juga dinilai lebih praktis, hemat dan higienis karena dalam penggunaannya, cairan yang akan keluar tidak akan sebanyak bila menggunakan kemasan botol yang sebelumnya. Penggunaan botol flip-top dengan cara menekan bagian botol (bukan tutup). Isi cairan akan keluar hanya ketika botol ditekan. Jadi, ketika botol tersebut dalam keadaan terbalik dan tutup atas terbuka, isinya tidak akan keluar karena tutupnya sudah didesain sebaik mungkin dan memiliki sistem pengunci sehingga cairan tidak mudah tumpah.

Warna botol yang transparan ini akan membuat isi sabun cair akan terlihat secara nyata. Konten dari kemasan botol ini sudah cukup mewakili apa yang diinginkan responden. Informasi seperti merk, keterangan kegunaan, volume, dan alamat pelaku usaha sudah tertera dalam desain kemasan botol yang baru ini. Informasi tersebut sudah tertera pada label yang dilengkapi dengan gambar sesuai dengan fungsi dan kegunaannya. Dalam hal ini adalah sabun cuci piring, sehingga gambar yang tertera yaitu peralatan rumah tangga seperti piring dan gelas. Label kemasan memadukan warna hijau sebagai warna dominan dan putih sebagai warna pendukung. Warna tulisan pada merk Star Sabun adalah warna merah, dan 
King Queenclong warna biru. Hal ini menambah keserasian warna pada kemasan sabun cair pencuci piring ini.

2. Desain 2 (Sabun Cuci Tangan)

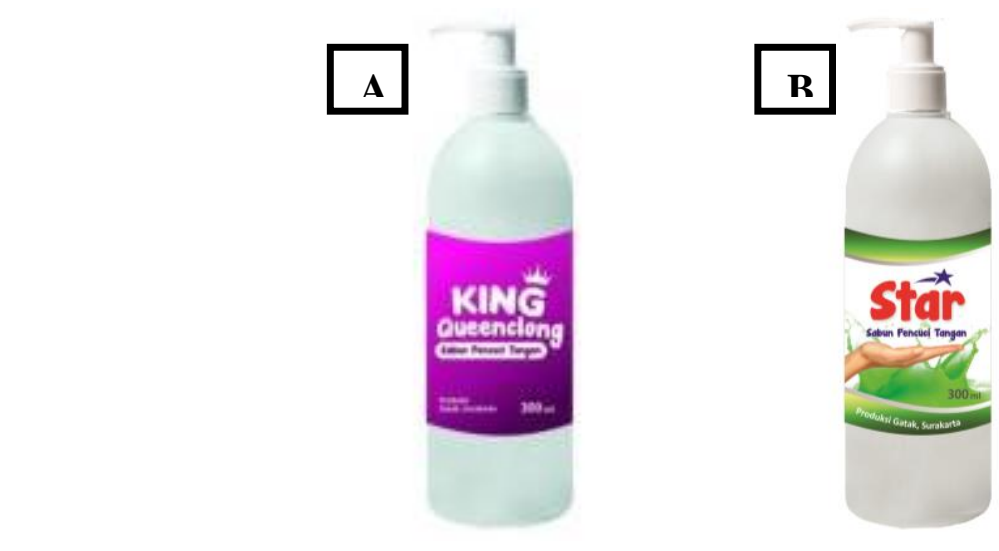

Gambar 4 (A) Desain sabun cuci tangan Star Sabun, (B) Desain sabun cuci tangan King Queenclong Sumber: Prameswari dkk, 2018

Penggunaan botol pump dinilai sangat praktis, hemat dan higienis seperti desain botol sebelumnya. Penggunaan botol pump adalah dengan menekan bagian tutup atas botol yang memiliki bentuk seperti selang. Dengan demikian, cairan yang ada di dalam botol sangat aman dan tidak akan mudah tumpah. Untuk sabun cuci tangan, dipilih bentuk kemasan botol pump ini agar mudah digunakan oleh para pengguna sabun. Informasi seperti merek, keterangan kegunaan, volume, dan alamat pelaku usaha juga tertera dalam desain kemasan botol cuci tangan ini. Label kemasan untuk sabun cuci tangan King Queenclong memadukan warna ungu dengan tulisan warna putih. Sedangkan untuk sabun cuci tangan Star Sabun memadukan warna tulisan merah dan biru, warna latar belakang memadukan warna hijau dan putih. Dengan bentuk kemasan, fungsi, dan perpaduan warna pada label akan menambah daya tarik para calon pelanggan untuk membeli sabun cuci tangan ini. 
Hal tersebut mendorong para produsen agar dapat membuat tampilan kemasan suatu produk semenarik mungkin sehingga menarik minat para konsumen. Konsumen tentunya memiliki berbagai macam alternatif untuk memilih produk yang akan mereka beli, alternatif tersebut timbul berdasar pada citra positif dari suatu brand produk.

\section{KESIMPULAN}

Perkembangan jumlah industri rumah tangga dari tahun ke tahun semakin bertambah. Dalam suatu industri kecil terdapat beberapa aspek yang dibutuhkan untuk bisa mendukung berjalannya suatu industri tersebut, diantaranya adalah modal, bahan baku, tenaga kerja, pemasaran, serta konsumen. Desain pemasaran merupakan salah satu hal utama dalam upaya pengembangan hasil penjualan. Desain dapat menjadi salah satu hal yang dipertimbangkan oleh konsumen ketika ingin membeli suatu produk. Hal ini dikarenakan pelaku industri menggunakan bungkus sekaligus untuk promosi.

Terdapat 3 aspek yang dilihat oleh konsumen dari produk penjualan sabun herbal meliputi bentuk (desain), isi dan harga. Konsumen lebih cenderung tertarik untuk memilih kemasan sabun dengan bentuk yang higienis dan efisien yaitu botol dengan tutup flip top dan kemasan botol pump dengan volume $300 \mathrm{ml}$. Penggunaan botol flip top dinilai lebih praktis dalam penggunaanya dibandingkan dengan botol lain. Selain itu, botol flip top lebih higienis jika digunakan, dan meminimalisir tumpahnya cairan. Sedangkan untuk pemilihan botol pump dinilai lebih efektif karena penggunaanya sekali tekan sehingga penggunaan lebih hemat dan menghindari tumpahnya cairan. Kemasan botol dengan warna bening atau putih lebih menarik. Warna utama yang diinginkan adalah bening/transparan dan warna pendukungnya adalah warna hijau. Selain itu, responden menginginkan adanya informasi konten yang perlu ditampilkan pada label kemasan, diantaranya adalah merek, komposisi dan fungsi atau kegunaan. Dengan demikian, inovasi 
branding ini dapat memberi dorongan secara tidak langsung kepada konsumen yang potensial untuk membeli produk sabun cair King Queenclong dan Star Sabun Herbal.

\section{DAFTAR PUSTAKA}

Aaker, D., 2014. Aaker On Branding. Jakarta: PT Gramedia Pustaka Utama.

Alma, B., 2002. Manajemen Pemasaran dan Pemasaran Jasa. Bandung: Alfabeta. Anandia, R., 2015. Analisa Pengaruh Desain Produk, Presepsi Harga, Dan Kualitas Produk terhadap Citra Merek Untuk Meningkatkan Minat Beli Konsumen Sepatu Adidas Original. Jurnal Manajemen, 1(1), pp.1-7.

Anggraini, D., Rahmides, W. S., \& Malik, M., 2012. Formulasi Sabun Cair dari Ekstrak Batang Nanas (Ananas comosus. L) untuk Mengatasi Jamur Candida Albicans. Jurnal Penelitian Farmasi Indonesia, 1(1), pp.30-33.

Cahyorini, A., dan Rusfian, E. Z., 2011. The Effect of Packaging Designn Impulse Buying. Jurnal of Administrative Science \& Organization, 18(1), pp.11-21.

Denzin, N.K., dan Lincoln, Y.S., 2009. Handbook of Qualitative Research. California: Sage Publication, Inc.

Grundey, D., 2010. Functionality of Product Packaging: Surveying Consumers Attitude Towards Selected Cosmetic Brands. Economics \& Sociology, 3(1), pp.87-103.

Haro, A., Agung, AWS. W., \& Agung, W. H., 2017. Peningkatan Keterampilan Bagi Ibu Rumah Tangga dalam Rangka Penghematan Melalui Pembuatan Sabun Cair Sederhana. Jurnal Pemberdayaan Masyarakat Madani, 1(2), pp:194-206.

Hasanah, H., 2016. Teknik-Teknik Observasi (Sebuah Alternatif Metode Pengumpulan Data Kualitatif Ilmu-ilmu Sosial). Jurnal at-Taqaddum, 8(1), pp.21-46.

Hidayat, G. R. M., Bahruddin, A. K., \& Riqqoh, 2016. Perancangan Brand Identity Xinxin Home industry Berbasis Nature Sebagai Upaya Peningkatan Brand Awareness. Art Nouveau, 5(2), pp.1-11.

Irrubai, M. L., 2016. Srategi Labelling, Packaging dan Marketing Produk Hasil Industry Rumah Tangga. Social Science Education Journal, 3(1), pp.17-26. 
Karedza, G., dan Sikwila, M., 2017. The Impact of Packaging Designs on Consumer Buying Behaviour of FMCG during the Hyperinflationary and After the Dollarisation Era in Zimbabwe. Asian Journal of Social Sciences and Management Studies, 4(1), pp.20-30.

Klimchuk, M. R., dan Krasovec, S. A., 2007. Desain Kemasan. Jakarta: Erlangga. Knapp, Duane E., 2001. The Brand Mind Set. Yogyakarta: ANDI

Kotler, P., dan Armstrong, G., 2012. Prinsip-Prinsip Pemasaran. Jakarta: Erlangga Kusno, F., Radityani, A., \& Kristanti, M., 2007. Analisa Hubungan Brand Strategy yang Dilakukan Goota Japanese Charcoal Grill and Cafe dan Brand Equity yang Sudah Diterima Konsumen. Jurnal Manajemen Perhotelan, 3(1), pp.43-56.

Lieven, T., Grohmann, B., Herrmann, A., Landwehr, J. R., dan Tilburg, M. V., 2015. Brand Design on Brand Gender Perceptions and Brand Preference. European Journal of Marketing, 49(1), pp.146 - 169.

Maflahah, I., 2012. Desain Kemasan Makanan Tradisional Madura Dalam Rangka Pengembagan IKM. Agrointek, 6(2), pp.1-9.

Mukhtar, S., dan Nurif, 2015. Peranan Packaging Dalam Meningkatkan Hasil Produksi Terhadap Konsumen. Jurnal Sosial Humaniora, 8(2), pp.181-191.

Pesoth, M. C., 2015. Pengaruh Kualitas Produk, Packaging, dan Brand Image Terhadap Kepuasaan Pelanggan Pada Perusahaan Rokok Dunhill di Kota Manado. Jurnal EMBA, 3(3), pp.1101-1112.

Sari, T.I., J. P. Kasih, T. J. N. Sari, 2010. Pembuatan Sabun Padat dan Sabun Cair dari Minyak Jarak. Jurnal Teknik Kimia, 17(1), pp:28-33.

Sasono, E., dan Yuliana, R., 2014. Manajemen Inovasi Pada Usaha Kecil Menengah. Jurnal STIE Semarang, 6(3), pp:74-90

Septiningtyas, A., dan Soewardikoen, D. W., 2018. Perancangan Identitas Visual dan Promosi Sasirangan Banjarbaru. Demandia, 3(1), pp.1-18

Silayoi dan Speece, 2004. Packaging and Purchase Decisions: An Exploratory Study on The Impact Of Involvement Level and Time Pressure. British Food Journal, 106(8), pp.607-628.

Sohier, G. P., 2009. Journal of The Influence of The Product Package on Functional and Symbolic Associations of Brand Image. Recherche et Applications en Marketing (English Edition), 24(2), pp.37-51. 
Sugiyono. 2010. Metode Penelitian Pendidikan Pendekatan Kuantitatif, kualitatif, dan R\&D. Bandung: Alfabeta

Suharto, M., Ardhianto, D. T., Ismail, A. I., dan Prameswari, N. S., 2017. Pelatihan Pengelolaan Website Toko Online Bagi UMKM di Kawasan Pasar Tradisional Klewer Surakarta Sebagai Strategi Menghadapi Masyarakat Ekonomi Asean (MEA). Demandia, 2(2), pp.229-245

Susetyarsi, Th., 2012. Kemasan Produk Ditinjau Dari Bahan Kemasan, Bentuk Kemasan dan Pelabelan Pada Kemasan Pengaruhnya Terhadap Keputusan Pembelian Pada Produk Minuman Mizone di Kota Semarang. Jurnal STIE Semarang, 4(3), pp.19-28

Sutawikara, E. S., 2017. Nilai Fungsional dan Estetik Kemasan/Wadah Berbahan Bambu Pada Makanan Tradisional Indonesia dan Jepang. Demandia, 2(2), pp.148-160

Sutojo, S., dan Kleinsteuber, F., 2002. Strategi manajemen pemasaran. Jakarta: Damar Mulia Pustaka.

Syamsudin, dan Wajdi, F., 2015. Desain Kemasan Makanan Kub Sukarasa di Desa Wisata Organik Sukorejo Sragen. BENEFIT Jurnal Manajemen dan Bisnis, 19(2), pp.68-78.

Tafiprios, dan Arbi, J.R., 2015. Evaluasi Desain Kemasan, Popularitas Merek dan Budaya Konsumen Terhadap Citra Merek Aqua. Jurnal IImiah Manajemen dan Bisnis, 1(3), pp.1-13.

Tjiptono, F., 2007. Strategi Pemasaran. Yogyakarta : Penerbit Andi

Widyasanti, A., Anisa Y. R., dan Sudaryanto Z., 2017. Pembuatan Sabun Cair Berbasis Virgin Coconut Oil (VCO) dengan Penambahan Minyak Melati (Jasminum sambac) Sebagai Essential Oil. Jurnal Teknotan, 11(2), pp.1-10

Wildyana \& Suyasa, P. T., 2006. Respon Terhadap Kemasan dan Intensi Membeli. Phronesis, Jurnal Ilmiah Psikologi Industri dan Organisasi, 8(2), pp.110-124. Zuhri, S., 2013, Analisis Pengembangan Usaha Kecil Home industry Sangkar Ayam Dalam Rangka Pengentasan Kemiskinan. Jurnal Manajemen dan Akuntansi, 2(3), pp.46-65 